\title{
Synthesis of Hetaryl-Substituted Asymmetric Porphyrins and Their Affinity to SARS-CoV-2 Helicase
}

\author{
S. A. Syrbu ${ }^{a}$, A. N. Kiselev ${ }^{a, b}$, M. A. Lebedev ${ }^{a, b}$, Yu. A. Gubarev ${ }^{a}$, \\ E. S. Yurina ${ }^{a, *}$, and N. Sh. Lebedeva ${ }^{a}$ \\ ${ }^{a}$ G.A. Krestov Institute of Solution Chemistry of the Russian Academy of Sciences, Ivanovo, 153045 Russia \\ ${ }^{b}$ Ivanovo State University of Chemistry and Technology, Ivanovo, 153000 Russia \\ *e-mail: yurina_elena77@mail.ru
}

Received April 21, 2021; revised April 21, 2021; accepted May 6, 2021

\begin{abstract}
Novel porphyrin compounds containing benzothiazole, benzoxazole, and benzimidazole moieties have been prepared and their structures have been confirmed. Molecular docking of non-symmetric hetaryl-substituted porphyrins and chlorin e 6 with SARS-CoV-2 helicase has been carried out. The affinity of hetaryl-substituted porphyrins to this protein has been found significantly higher than that of the drugs approved by the FDA and chlorin e6. The structure of the complexes of SARS-CoV-2 helicase with the considered macroheterocyclic compounds has been analyzed. Possible ways to inhibit and photoinactivate SARS-CoV helicase have been suggested basing on the localization of porphyrins and chlorin e6 in the helicase domains.
\end{abstract}

Keywords: porphyrins, molecular docking, helicase, SARS-CoV-2 virus, inhibition, inactivation

DOI: $10.1134 / \mathrm{S} 1070363221060098$

The mankind currently experiences the outbreak of coronavirus disease Covid-19 induced by SARS-CoV-2 pathogen. As of April 2021, more than 133 million people have been infected, more than 2.9 million of then died. The patients with SARS-CoV-2 exhibit a wide range of clinical manifestations between light clinical course and rapidly progressing serious one, resulting in lethal outcome. In most cases, Covid-19 causes respiratory disorder, acute respiratory syndrome, and central nervous system disorder [1-3]. Individual manifestations of the disease are also possible. Penetration of the SARS-CoV-2 virus is mediated by the interaction of the virus S-protein with the angiotensin-converting enzyme 2 (ACE2). Since ACE2 is localized at the alveolar epithelial cells, enterocytes, Schneiderian membrane, oral epithelium, arterial and venous endotheliocytes, and arterial unstriped muscles, virus species are found in such organs as lungs, intestines, skin, spleen, and brain [4].

The studies aiming at the development of drugs to treat Covid-19 are in progress, yet generally it takes years to elaborate a drug, due to the duration of preclinical and clinical trials as well as the complexity of the creation of virucide drugs. The nature of coronavirus bearing a positive single-strand RNA genome is a further complication hindering the development of the antiviral drugs. Single-strand RNA viruses are very labile and readily mutate during replication and transcription phases [5-8], therefore it is almost impossible to develop a drug exhibiting high selectivity and affinity with respect to RNA. This is the case of the viruses of Ebola hemorrhagic fever, SARS, AIDS, hydrophobia, hepatitis C and E, West Nile encephalitis, and poliomyelitis, which have remained severe issues over several decades. Therefore, the SARS$\mathrm{CoV}-2$ genome has not been considered as a drug target, in contrast to the proteins of SARS-CoV-2. 4 structural proteins [S-protein, matrix (M) protein, shell protein (E), and nucleocapsid protein $(\mathrm{N})], 16$ nonstructural proteins (nsp1-nsp16), and several complementary proteins (ORF) can serve as the targets, the most evident of them being the S-protein of the virus spike [9-12]. Binding of a drug with this target will lead to the inhibition of the virus penetration in the cells and compete with the binding with ACE2. This strategy may not seem very productive, since the S-protein is prone to mutations, especially in the receptor-binding motif (RBM) responsible for the recognition of the ACE of the host cells. As per reference 
Table 1. Affinity of helicase to potential inhibitors of SARS$\mathrm{CoV}-2$

\begin{tabular}{l|c|c}
\hline \multicolumn{1}{c|}{ Compound } & Affinity, & References \\
& kcal/mol & \\
\hline Vapreotide & -12.88 & {$[16]$} \\
1b & -12.30 & This study \\
Cangrelor & -11.48 & {$[17]$} \\
Atazanavir & -11.28 & {$[16]$} \\
1a & -11.20 & This study \\
Nystatin & -11.10 & {$[18]$} \\
1c & -10.90 & This study \\
Lopinavir & -10.71 & {$[16]$} \\
Ivermectin & -10.70 & {$[18]$} \\
Elbasvir & -10.50 & {$[19]$} \\
Simeprevir & -10.42 & {$[20]$} \\
Cepharanthine & -10.30 & {$[21]$} \\
Ritonavir & -9.39 & {$[16]$} \\
Chlorin e6, complex A & -9.30 & This study \\
Grazoprevir & -9.15 & {$[20]$} \\
Chlorin e6, complex B & -9.00 & This study \\
Rilpivirine & -8.03 & {$[16]$} \\
Favipiravir & -4.65 & {$[16]$} \\
\hline
\end{tabular}

data [13], the amino acid sequences of the S-proteins of SARS-CoV-2 and SARS-CoV viruses isolated from human, civet, and bat were similar by $76-78 \%$ for the overall protein, $73-76 \%$ for the receptor-binding domain, and $50-53 \%$ for RBM. Hence, the receptor-binding motif is the least conservative part of the coronaviruses S-protein. Therefore, more conservative SARS-CoV-2 protein, helicase, seems more promising target [14].

Helicase is a nonstructural coronavirus protein required for its replication, it is responsible for untwisting of the nucleic acid and separation of double-strand nucleic acids into the single-strand ones [14]. Two helicase molecules (along with the RNA-polymerase and the nonstructural proteins nsp7 and nsp8) constitute the complex of minireplication and transcription of SARS-CoV-2. Helicase can be complementary bound to the nonstructural proteins [15], and we have suggested that the formation of strong complex with helicase can inhibit this enzyme. A series of known compounds approved for the clinical application can be bound with helicase according to the molecular docking data (Table 1).

However, these compounds do not exhibit virucide properties. Such action is typical of porphyrin compounds which can generate singlet oxygen upon visible light irradiation and thus oxidize the amino acid moieties of the polypeptide chain [22-26]. The change in the primary structure of the protein upon photooxidation can lead to complete loss of its functional activity. Nonsymmetrical hetaryl-substituted porphyrins 1a-1c 5-[4-(1,3-benzothiazol-2-yl)phenyl]-10,15,20-tris(1methylpyridin-3-yl)porphyrin triiodide (1a, $X=S)$, 5-[4-(1,3-benzoxazol-2-yl)-phenyl]-10,15,20-tris(1methylpyridin-3-yl)porphyrin triiodide $(\mathbf{1 b}, \mathrm{X}=\mathrm{O})$, 5-[4-(1-methyl-1,3-benzimidazol-2-yl)phenyl]-10,15,20-

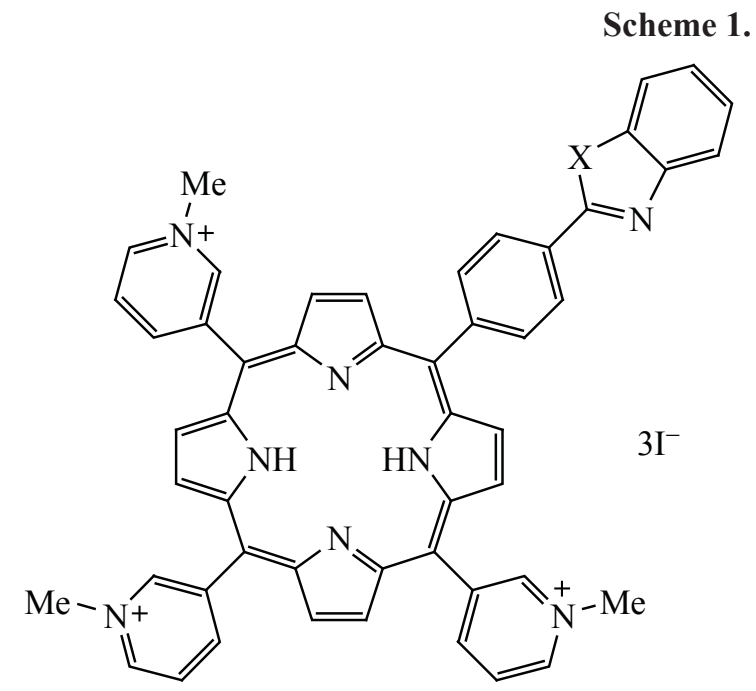

1a-1c<smiles></smiles>

2 
Scheme 2.

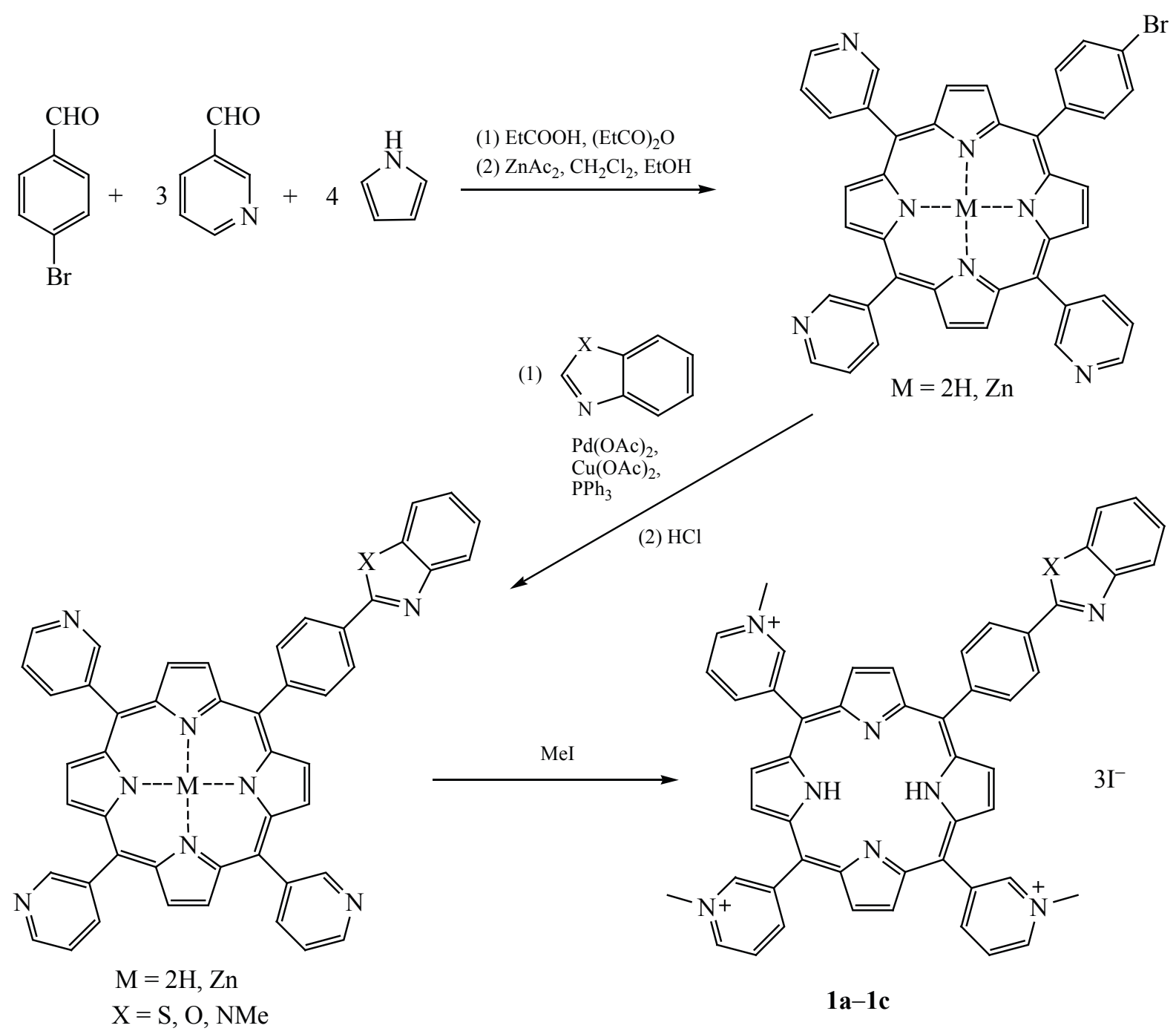

$\mathrm{M}=2 \mathrm{H}, \mathrm{Zn} ; \mathrm{X}=\mathrm{S}(\mathbf{1 a}), \mathrm{O}(\mathbf{1 b}), \mathrm{NMe}(\mathbf{1 c})$.

tris(1-methylpyridin-3-yl)porphyrin triiodide (1c, $\mathrm{X}=$ $\mathrm{NCH}_{3}$ ) - and chlorin e6 2 (a drug used for photodynamic therapy of oncological diseases) (Scheme 1) were used as potential sensibilizers.

The chosen nonsymmetric substituted porphyrins 1a-1c have not been described in the literature. They were synthesized according to Scheme 2. Compounds 1a-1c were characterized by spectral methods, their purity was confirmed by means of TLC.

The choice of porphyrins 1a-1c was due to several reasons. First, the presence of the hetaryl fragments allowed H-binding with the amino acid residues; second, it imparts the stable wedge-shape structure of the porphyrin compound, which also favors the binding with the protein. The introduction of the $\mathrm{NCH}_{3}$ groups at the peripheral substituents enhances the solubility of the hetaryl-substituted porphyrins in aqueous media as well as primary binding of helicase. The map of the surface electrostatic potential created using PyMOL system clearly demonstrated that SARS-CoV-2 helicase was a highly basic protein (Fig. 1). Extensive regions of the negative potential at the protein surface determine strong binding of polycationic compounds (hetaryl-substituted porphyrins). Helicase regions bearing the positive charge at the surface can interact with chlorin e6.

SARS-CoV-2 helicase consists of the following domains: The N-terminal zinc-binding domain ZBD 

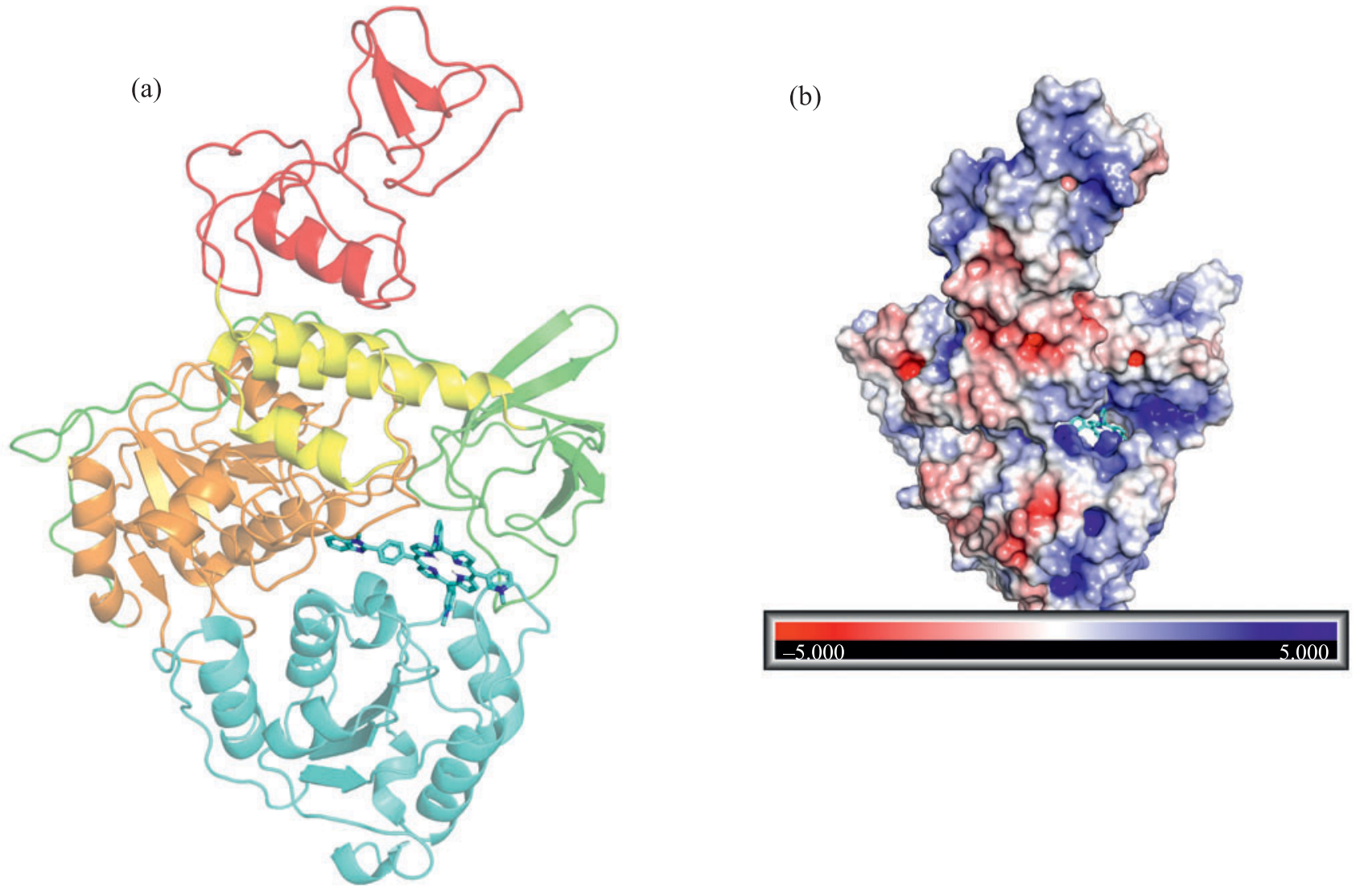

(c)

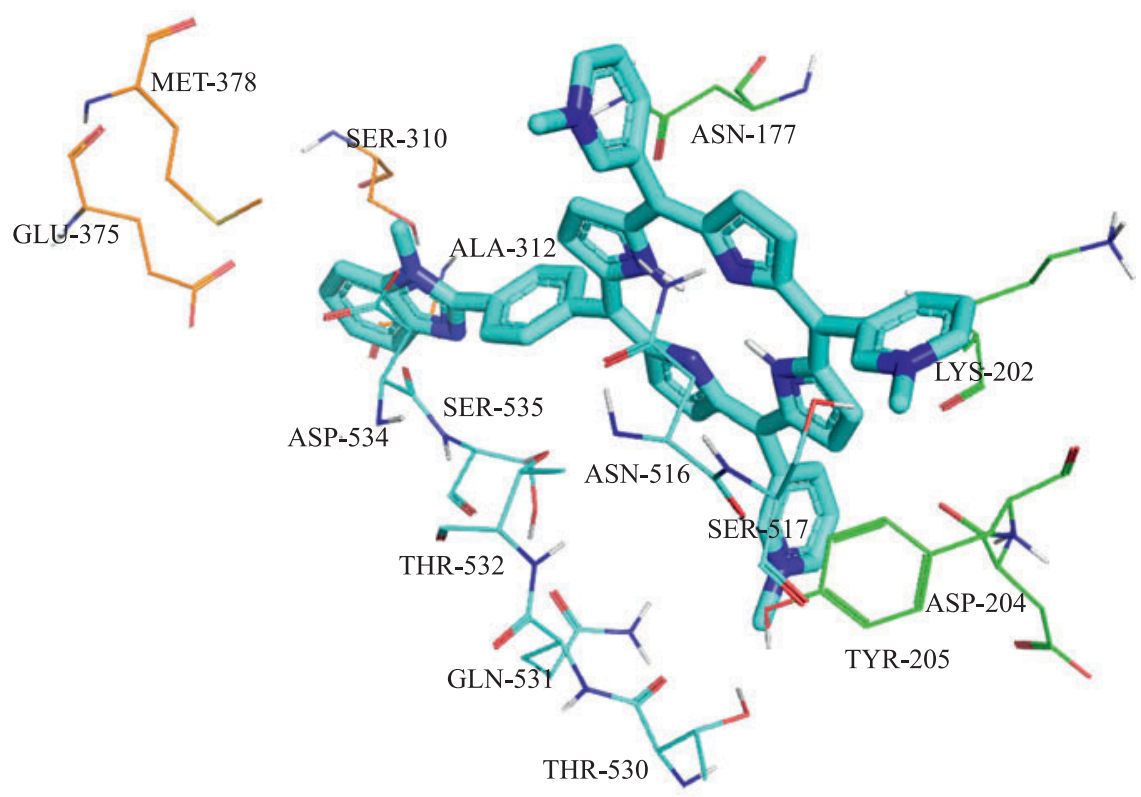

Fig. 1. Molecular docking of 5-[4-(1-methyl-1,3-benzimidazol-2-yl)phenyl]-10,15,20-tris(1-methylpyridin-3-yl)porphyrin with SARSCov-2 helicase. (a) general view of the complex, (b) electrostatic potential of the complex surface, (c) structure of the complex. 
Table 2. Structure description of helicase complexes with hetaryl-substituted porphyrins $\mathbf{1 a}-\mathbf{1 c}$ and chlorin e6

\begin{tabular}{|c|c|c|}
\hline Compound & Amino acid surrounding in the radius of $4 \AA$ & $\begin{array}{l}\text { Hydrogen bonds of the peripheral substituent } \\
\text { in the porphyrin with the amino acid residue of } \\
\text { helicase }(d, \AA)^{\mathrm{a}}\end{array}$ \\
\hline $1 \mathrm{~b}$ & $\begin{array}{llll}\text { ASN177, } & \text { ASN 179, } & \text { GLU201, } & \text { LYS202, } \\
\text { TYR205, } & \text { SER310, } & \text { GLU375, } & \text { MET378, } \\
\text { PRO408, } & \text { ASN516, } & \text { ALA520, } & \text { GLN53, } \\
\text { ASP534, } & \text { SER535, } & \text { GLN537, } & \text { HIS554, } \\
\text { ARG560 } & & & \end{array}$ & No \\
\hline $1 \mathbf{a}$ & $\begin{array}{llll}\text { ASN177, } & \text { ASN179, } & \text { GLU201, } & \text { LYS202, } \\
\text { ASP204, } & \text { TYR205, } & \text { SER310, } & \text { ALA312, } \\
\text { GLU375, } & \text { MET378, } & \text { PRO408, } & \text { ASN516, } \\
\text { SER517, } & \text { ALA520, } & \text { THR530, } & \text { GLN531, } \\
\text { THR532, } & \text { ASP534, } & \text { SER535, } & \text { GLN537, } \\
\text { HIS554, } & \text { ARG560 } & & \end{array}$ & No \\
\hline $1 \mathrm{c}$ & $\begin{array}{lrrr}\text { ASN177, } & \text { LYS202, } & \text { ASP204, } & \text { TYR205, } \\
\text { SER310, ALA312, } & \text { GLU375, } & \text { MET378, } \\
\text { ASN516, } & \text { SER517, } & \text { THR530, } & \text { GLN531, } \\
\text { THR532, ASP534, SER535 } & \end{array}$ & No \\
\hline Chlorin e6, complex A & $\begin{array}{llll}\text { ASN177, } & \text { ASN179, } & \text { PRO406, } & \text { PRO408, } \\
\text { LEU412, } & \text { THR413, } & \text { LYS414, } & \text { GLY415, } \\
\text { THR416, } & \text { LEY417, } & \text { PHE422, } & \text { ASP534, } \\
\text { ASN557, ASN559, ARG560 } & \end{array}$ & $\begin{array}{l}\text { GLY415 (2.7), LEY417 (1.9), ASN557 (3.1), } \\
\text { PRO408 (3.8) }\end{array}$ \\
\hline Chlorin e6, complex B & $\begin{array}{llll}\text { PRO284, } & \text { GLY285, } & \text { THR286, } & \text { GLY287, } \\
\text { LYS288, } & \text { SER289, } & \text { HIS290, } & \text { ALA312, } \\
\text { ALA313, } & \text { ALA316, } & \text { GLU319, } & \text { LYS320, } \\
\text { LYS323, } & \text { ASP374, } & \text { ARG443, } & \text { GLY538, } \\
\text { GLU540 } & & & \end{array}$ & $\begin{array}{l}\text { GLY285 (1.6, 3.3), GLY538 (3.1), THR286 } \\
\text { (2.9), GLY287 (2.0), LYS288 (1.7), HIS290 } \\
\text { (1.5), SER289 (3.0) }\end{array}$ \\
\hline
\end{tabular}

${ }^{\mathrm{a}} \mathrm{H}$-Bond with the $\mathrm{N}$ atom in the reactive site.

(amino acids 1-99), rod-like domain $\mathrm{S}$ (amino acids 100-149), domain 1B (amino acids 151-260), domain $1 \mathrm{~A}$ (amino acids 261-442), and domain 2A (amino acids 442-596) (Fig. 1) [27].

Non-symmetrical hetaryl-substituted porphyrins 1a-1c revealed single-site binding with SARS-CoV-2 helicase. As an example, Fig. 1 shows the results of molecular docking of porphyrin 1c with the helicase.

Porphyrins 1a-1c were interposed between the 1A, $2 \mathrm{~A}$, and $1 \mathrm{~B}$ domains. The conformations of complexes of porphyrin 1c (bearing the benzimidazole residue) with the hetaryl fragment located between the $1 \mathrm{~A}$ and $2 \mathrm{~A}$ domains were the most energetically favorable (Fig. 1). As for the helicase complexes with porphyrins 1a, 1b (bearing benzothiazole and benzoxazole residues), their most favorable conformations corresponded to the location of the hetaryl fragment in the 1B domain (Fig. 2).
Affinity of helicase with respect to the hetarylsubstituted porphyrins was increased with the substitution of the $\mathrm{NCH}_{3}$ group in the peripheral substituent with a sulfur and oxygen atom (Table 1). Porphyrins 1a-1c did not form specific $\pi-\pi$ or H-bonds with the amino acid residues (Table 2). High affinity of helicase to porphyrin 1b containing the benzoxazole residue was likely due to the optimal geometry and electrostatic correspondence of the binding site and the porphyrin.

Only several potential inhibitors of SARS-CoV-2 helicase considered in the literature revealed the binding energy comparable to the affinity values obtained for porphyrins 1a-1c (Table 1). Binding energy of other compounds is lower. Hence, porphyrins 1a-1c could serve as potential helicase inhibitors. As was marked above, the compounds capable of complete inactivation of the enzyme are the most promising for further studies. The possibility of helicase photooxidation under the action of 


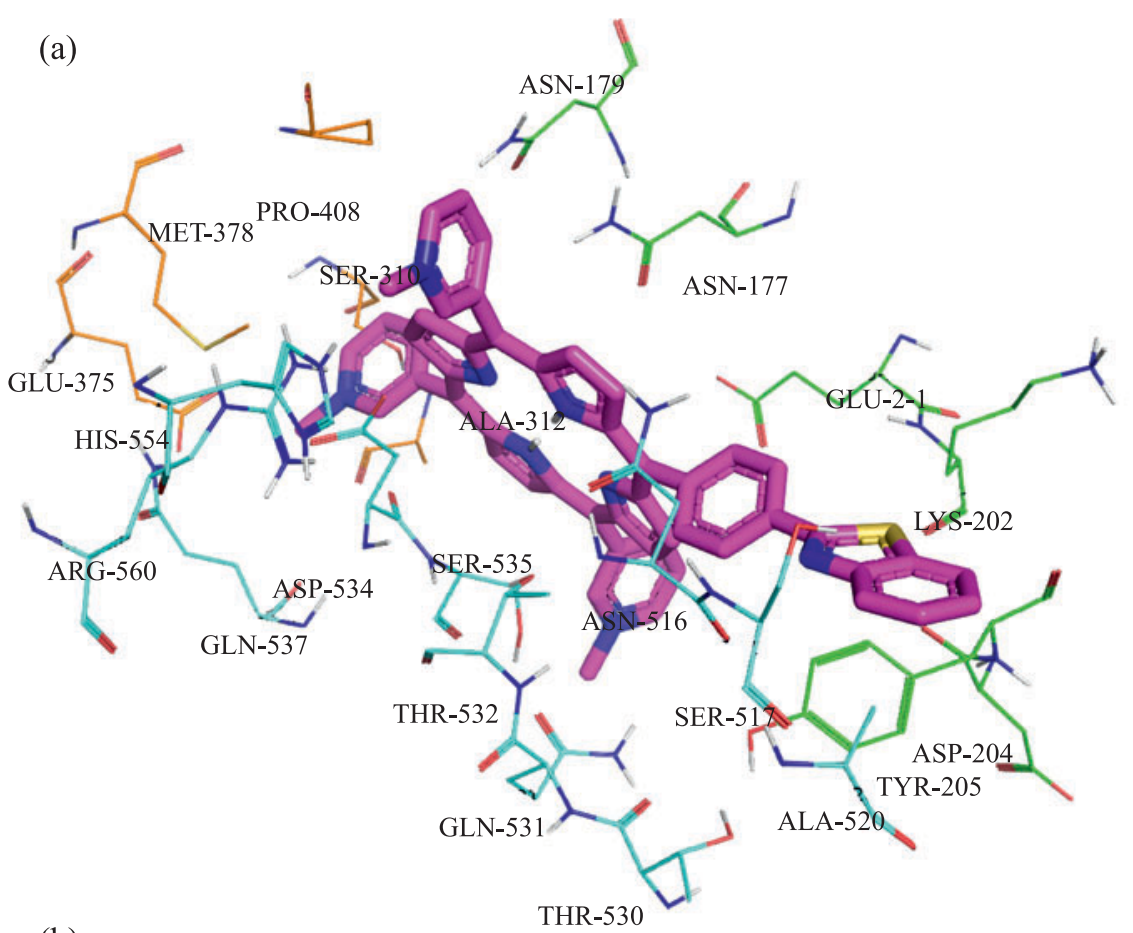

(b)

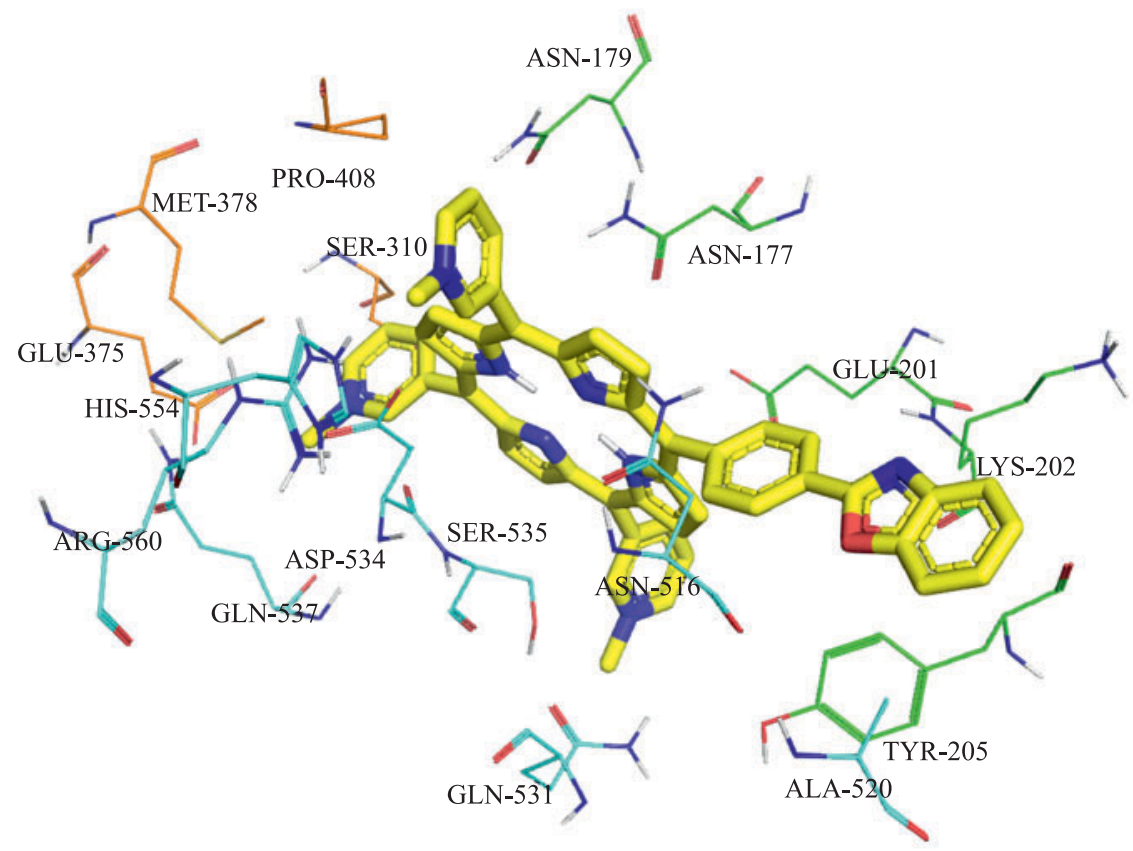

Fig. 2. Amino acid surrounding in the radius of $4 \AA$ from 5-[4-(1,3-benzothiazol-2-yl)phenyl]-10,15,20-tris(1-methylpyridin-3-yl)porphyrin (a) and 5-[4-(1,3-benzoxazol-2-yl)phenyl]-10,15,20-tris(1-methylpyridin-3-yl)porphyrin (b) in the complex with SARSCoV-2 helicase.

porphyrins 1a-1c should depend on the photoactivity of the porphyrin as well as the presence of the amino acid residues prone to the photooxidation and their distance from the porphyrin. These amino acids include cysteine, methionine, tryptophane, tyrosine, and histidine; rate constant of their reaction with ${ }^{1} \mathrm{O}_{2}$ equals $8.9 \times 10^{6}$, $1.6 \times 10^{7}, 3.0 \times 10^{7}, 8 \times 10^{6}$, and $3.2 \times 10^{7} \mathrm{~mol}^{-1} \mathrm{~L} \mathrm{~s}^{-1}$, respectively [28]. The distance which reactive singlet 
(a)

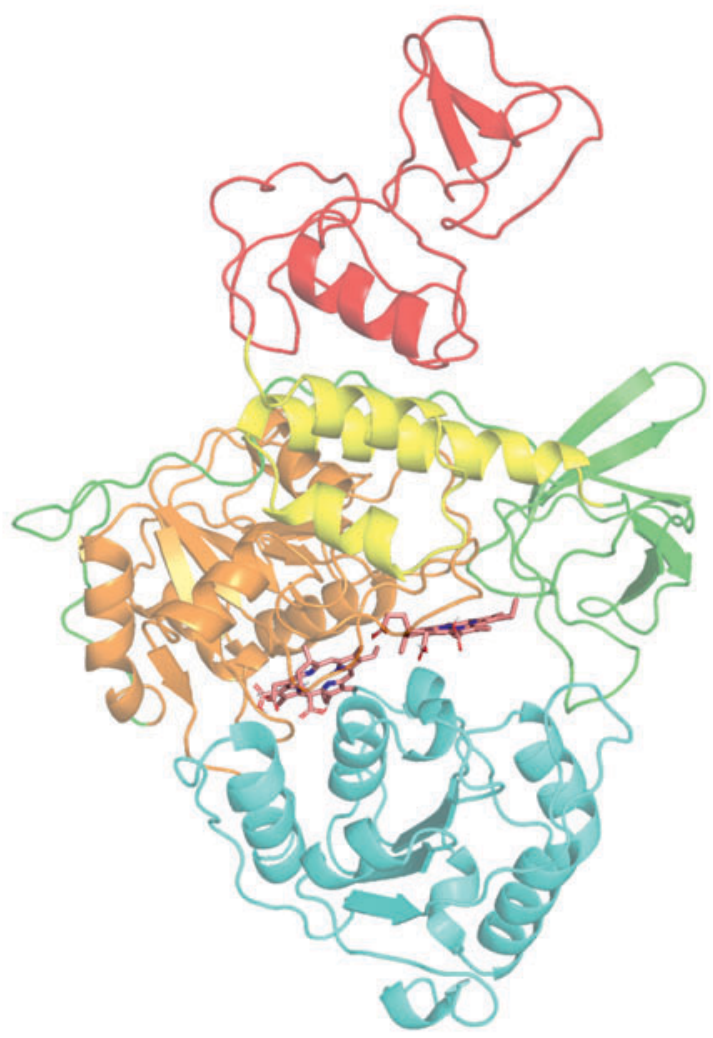

(c)

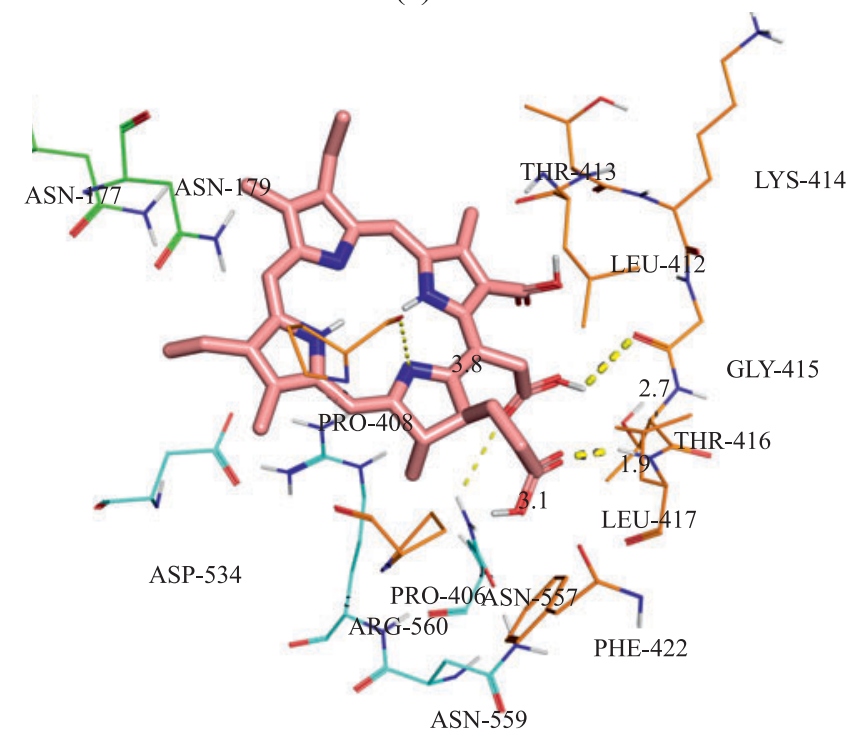

(b)

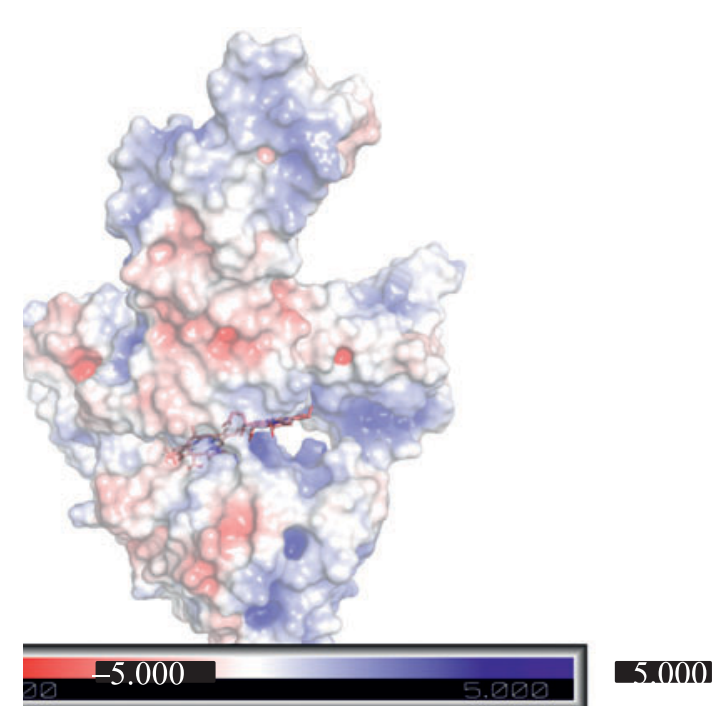

(d)

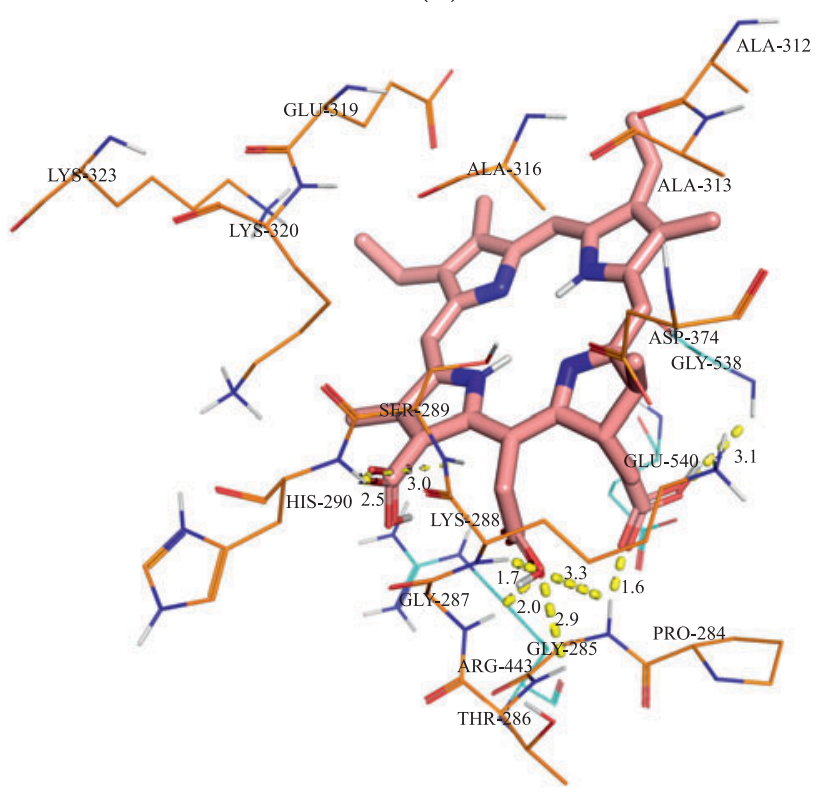

Fig. 3. Molecular docking of chlorin e6 with SARS-CoV-2 helicase. (a) general view of the complex, (b) electrostatic potential of the complex surface, (c) structure of the complex A, (d) structure of the complex B. H-Bonds are shown with dashed line. 
oxygen can pass in the virus protein can hardly be estimated. According to the reference data, the longest path of ${ }^{1} \mathrm{O}_{2}$ in an aqueous medium in the absence of any quencher does not exceed $150 \mathrm{~nm}$ [29], the region of inside-cell activity of singlet oxygen in living cells is of $100-150 \mathrm{~nm}[30,31]$. It could be suggested that the cysteine, methionine, tryptophane, tyrosine, and histidine moieties present in the nearest amino acid surrounding of the hetaryl-substituted porphyrins will likely undergo photooxidation. According to the obtained data, the following vulnerable restudies were located at distance from porphyrins 1a, 1b not exceeding $4 \AA$ : TYR205 (site 1B), MET378 (site 1A), and HIS 554 (site 2A); the vulnerable amino acid units close to porphyrin 1c were TYR205 (site 1B) and MET378 (site 1A). The data on the molecular docking suggest the porphyrins $\mathbf{1 a}-\mathbf{1 c}$ can inhibit the SARS-CoV-2 helicase and disrupt its primary structure.

Chlorin e6 could be bound to the helicase at two sites (Fig. 3), the highest affinity (complex A, Table 1) was revealed for chlorin e6 localized between the $1 \mathrm{~A}, 2 \mathrm{~A}$, and $1 \mathrm{~B}$ domains. Somewhat lower affinity was observed for complex $\mathbf{B}$, in which chlorin interacted with the amino acid residues of domains $2 \mathrm{~A}, 1 \mathrm{~A}$, and $\mathrm{S}$.

Oxygen atoms in the nonsymmetrical substituted chlorin e6 molecule could form the hydrogen bonds in both complexes (Fig. 3, Table 2). A weak hydrogen bond between the $\mathrm{N}$ atom of the porphyrin site and the PRO408 residue of the polypeptide chain was formed in complex A. However, the affinity of helicase to chlorin e6 was relatively low (Table 1), likely due to nonoptimal electrostatic interactions and poor structural correspondence, since chlorin e6 was located almost at the protein surface (Fig. 3); therefore, it could not be considered an efficient inhibitor (Table 1). Both binding sites did not contain amino acid units vulnerable to the action of ${ }^{1} \mathrm{O}_{2}$ [28], except for the HIS290 residue in complex $\mathbf{B}$ involved in the hydrogen bonding with the peripheral carboxylic groups of chlorin e6 (Table 2). In view of the amino acid surrounding of chlorin e6 in its complexes $\mathbf{A}$ and $\mathbf{B}$ with helicase, its virucide action was unlikely.

In summary, molecular docking of SARS-CoV-2 helicase with novel nonsymmetric hetaryl-substituted porphyrins bearing benzothiazole, benzoxazole, and benzimidazole moieties as well as with chlorin e6 revealed that those compounds could inhibit and completely inactivate the enzyme essential for SARS-CoV-2 virus replication. Since this protein is highly conservative, it can be suggested that the considered porphyrins can be active towards helicase of different strains of the virus. The obtained theoretical results should be confirmed by the experiment.

\section{EXPERIMENTAL}

The structure of SARS-CoV-2 QHD43415_12 helicase was taken from the https://zhanglab.ccmb. med.umich.edu/CoVID-19/ database. Structures of chlorin e6 and hetaryl-substituted porphyrins containing benzothiazole (1a), benzoxazole (1b), and benzimidazole (1c) groups were optimized using the DFT b3lyp. method implemented in ORCA 4.0 software [32]. Molecular docking of the protein with porphyrins $\mathbf{1 a}-\mathbf{1 c}$ and chlorin e6 was performed using AutoDock Vina 1.1.2 software [33] and visualized using PyMOL software. The PDBQT files describing the compounds structures were created using AutoDockTools 1.5.6 software, and then the three-dimensional field was set in the same program, and the docking parameters file was obtained. Upon the computation, the results were visualized in the PyMOL system, and the protein-porphyrin interaction energy was assessed.

Electronic absorption spectra of compounds 1a-1c in dichloromethane over $\lambda 200-1000 \mathrm{~nm}$ were obtained at room temperature using a UV/VIS Hitachi U2001 spectrophotometer (Japan). ${ }^{1} \mathrm{H}$ NMR spectra were recorded using a Bruker Avance-500 instrument (USA) using the solvents signals as internal reference. MALDITOF mass spectra (positive ions mode) were recorded using a Shimandzu AXIMA Confidence (Japan) mass spectrometer as well as a Bruker Daltonics Ultraflex instrument (USA).

The solvents were dried and distilled prior to use. The chemicals with purity of at least $99 \%$ (Reakhim, EKOS-1, Aldrich, and Fluka) were used.

5-(4-Bromophenyl)-10,15,20-tris(pyridin-3-yl)porphyrin. A mixture of $10 \mathrm{~mL}(0.144 \mathrm{~mol})$ of pyrrole, $6.66 \mathrm{~g}(0.036 \mathrm{~mol})$ of 4-bromobenzaldehyde, and $10.15 \mathrm{~mL}(0.108 \mathrm{~mol})$ of pyridine-3-carbaldehyde was added over $20 \mathrm{~min}$ to an aerated boiling solution of $500 \mathrm{~mL}$ of propionic acid and $35 \mathrm{~mL}(0.27 \mathrm{~mol})$ of propionic anhydride. The mixture was refluxed during $1.5 \mathrm{~h}$ with aeration. Propionic acid was distilled off under vacuum. $300 \mathrm{~mL}$ of methanol and $230 \mathrm{~mL}$ of ammonia solution were added to the residue. The precipitate (a mixture of porphyrins) was filtered off, 
washed with methanol, and dried at room temperature. The dried precipitate was dissolved in $200 \mathrm{~mL}$ of dichloromethane and subject to chromatography of a column with $\mathrm{Al}_{2} \mathrm{O}_{3}$ (Brockmann III) eluting with a $10: 1$ ethanol-dichloromethane mixture. The third fraction, 5-(4-bromophenyl)-10,15,20-tris(pyridin-3-yl)porphyrin, was collected. The solvent was evaporated off, and the porphyrin was again subject to chromatography on a column with $\mathrm{Al}_{2} \mathrm{O}_{3}$ (Brockmann III) eluting with a 10 : 1 ethanol-dichloromethane mixture. The product purity was confirmed by means of TLC on Alufol and MALDITOF mass spectrometry. Yield $3.95 \mathrm{~g}(15.8 \%) . R_{\mathrm{f}} 0.72$ (Silufol, dichloromethane-ethanol, $10: 1$ ). Electronic absorption spectrum (dichloromethane), $\lambda_{\max }, \mathrm{nm}(\log \varepsilon)$ : 416 (5.91), 512 (4.60), 547 (4.58), 588 (4.48), 643 (4.58).

${ }^{1} \mathrm{H}$ NMR spectrum $\left(\mathrm{CDCl}_{3}\right), \delta, \mathrm{ppm}(J, \mathrm{~Hz}): 9.50 \mathrm{~s}(3 \mathrm{H}$, $\left.\mathrm{H}^{2^{\prime}}, \mathrm{Py}\right), 9.10 \mathrm{~d}\left(3 \mathrm{H}, \mathrm{H}^{6^{\prime}}, \mathrm{Py}, J=5.5\right), 9.02 \mathrm{~d}\left(2 \mathrm{H}, \mathrm{H}^{8,12}\right.$, $J=4.5), 8.89 \mathrm{~s}\left(4 \mathrm{H}, \mathrm{H}^{3,7,13,17}\right), 8.57 \mathrm{~d}\left(2 \mathrm{H}, \mathrm{H}^{2,18}, J=4.5\right)$, $8.44 \mathrm{~d}\left(3 \mathrm{H}, \mathrm{H}^{4^{\prime}}, \mathrm{Py}, J=5.5\right), 8.07 \mathrm{~d}\left(2 \mathrm{H}, \mathrm{H}^{2 \prime}, 6^{\prime \prime}, \mathrm{Ph}, J=\right.$ $8.0), 7.91 \mathrm{~d}\left(5 \mathrm{H}, \mathrm{H}^{5^{\prime}}, \mathrm{H}^{3^{\prime \prime}, 5^{\prime \prime}}, \mathrm{Ph}, J=8.0\right),-2.78 \mathrm{~s}(2 \mathrm{H}$, $\mathrm{NH}$ ). Mass spectrum (MALDI-TOF), $m / z: 696.68[M]^{+}$. $\mathrm{C}_{41} \mathrm{H}_{26} \mathrm{BrN}_{7} . M 696.60$.

Zinc 5-(4-bromophenyl)-10,15,20-tris(pyridin-3-yl)porphyrinate. $3 \mathrm{~g}$ (4.3 mmol) of 5-(4-bromophenyl)10,15,20-tris(pyridin-3-yl)porphyrin and $4.7 \mathrm{~g}$ $(0.021 \mathrm{~mol})$ of anhydrous zinc acetate were dissolved in a mixture of $200 \mathrm{~mL}$ of methanol and $100 \mathrm{~mL}$ of methylene chloride. The mixture was refluxed during $1.5 \mathrm{~h}$ monitoring the reaction course by means of electronic absorption spectroscopy. The mixture was cooled down and subject to chromatography of a column with $\mathrm{Al}_{2} \mathrm{O}_{3}$ (Brockmann III) eluting with a $10: 1$ ethanol-dichloromethane mixture. The solvent was distilled off under vacuum, the residue was washed with water, filtered off, and dried at room temperature to constant mass. Yield $3.2 \mathrm{~g}(98 \%) . R_{\mathrm{f}} 0.67$ (Silufol, dichloromethane-ethanol, $10: 1)$. Electronic absorption spectrum (dichloromethane), $\lambda_{\max }, \mathrm{nm}(\log \varepsilon): 416$ (6.06), 549 (4.62), 590 (4.71). ${ }^{1} \mathrm{H}$ NMR spectrum $\left(\mathrm{CDCl}_{3}\right), \delta$, ppm $(J, \mathrm{~Hz}): 9.50 \mathrm{~s}\left(3 \mathrm{H}, \mathrm{H}^{2^{\prime}}, \mathrm{Py}\right), 9.10 \mathrm{~d}\left(3 \mathrm{H}, \mathrm{H}^{6^{\prime}}, \mathrm{Py}\right.$, $J=5.5), 9.02 \mathrm{~d}\left(2 \mathrm{H}, \mathrm{H}^{8,12}, J=4.5\right), 8.89 \mathrm{~s}\left(4 \mathrm{H}, \mathrm{H}^{3,7,13,17}\right)$, $8.57 \mathrm{~d}\left(2 \mathrm{H}, \mathrm{H}^{2,18}, J=4.5\right), 8.44 \mathrm{~d}\left(3 \mathrm{H}, \mathrm{H}^{4^{\prime}}, \mathrm{Py}, J=5.5\right)$, $8.07 \mathrm{~d}\left(2 \mathrm{H}, \mathrm{H}^{2 \prime}, 6^{\prime \prime}, \mathrm{Ph}, J=8.0\right), 7.92 \mathrm{~d}\left(5 \mathrm{H}, 5^{\prime}-\mathrm{HPy}, \mathrm{H}^{3 ", 55^{\prime \prime}}\right.$, $\mathrm{Ph}, J=8.0$ ). Mass spectrum (MALDI-TOF), $m / z: 760.03$ $[M]^{+} . \mathrm{C}_{41} \mathrm{H}_{24} \mathrm{BrN}_{7} \mathrm{Zn} . M 759.97$.

5-[4-(1,3-Benzothiazol-2-yl)phenyl]-10,15,20tris(pyridin-3-yl)porphyrin. A mixture of $0.03 \mathrm{~g}$ of $\mathrm{Pd}(\mathrm{OAc})_{2}(20 \mathrm{~mol} \%), 0.026 \mathrm{~g}$ of $\mathrm{Cu}(\mathrm{OAc})_{2} \cdot \mathrm{H}_{2} \mathrm{O}$
(20 mol \%), $0.176 \mathrm{~g}$ of triphenylphosphine (1 eq.), $0.51 \mathrm{~g}$ of zinc 5 -(4-bromophenyl)-10,15,20-tris(pyridin3 -yl)porphinate $(0.671 \mathrm{mmol}), 45 \mathrm{~mL}$ of toluene, and $146 \mu \mathrm{L}$ ( 2 eq., $1.342 \mathrm{mmol}$ ) of benzothiazole was refluxed at stirring during $48 \mathrm{~h}$ and cooled down to ambient, then $50 \mathrm{~mL}$ of methylene chloride was added, and the mixture was filtered. The precipitate was washed with $10 \mathrm{~mL}$ of methylene chloride, and the combined organic fractions were evaporated in vacuum. The residue was dissolved in $30 \mathrm{~mL}$ of methylene chloride and subject to chromatography of a column with $\mathrm{Al}_{2} \mathrm{O}_{3}$ (Brockmann III) eluting first with dichloromethane and then with a $1: 10$ ethanol-dichloromethane mixture. The second fraction was collected. The zinc complex was dissolved in dichloromethane, and $3 \mathrm{~mL}$ of conc. $\mathrm{HCl}$ was added to decompose the complex. Then the mixture was treated with aqueous ammonia and washed with water. The solution was dried over anhydrous sodium sulfate and evaporated to dryness. The residue was subject to chromatography of a column with $\mathrm{Al}_{2} \mathrm{O}_{3}$ (Brockmann III) eluting first with dichloromethane and then with a $1: 10$ ethanol-dichloromethane mixture. The second fraction was collected. Yield $0.345 \mathrm{~g}(67 \%)$,green-violet crystalline powder. $R_{\mathrm{f}} 0.73$ (Silufol, dichloromethane-ethanol, $10: 1$ ). Electronic absorption spectrum (dichloromethane), $\lambda_{\max }, \mathrm{nm}(\log \varepsilon): 420$ (5.96), 516 (4.66), 550 (4.57), 590 (4.60), 646 (4.59). ${ }^{1} \mathrm{H}$ NMR spectrum $\left(\mathrm{CDCl}_{3}\right), \delta$, ppm $(J, \mathrm{~Hz}): 9.50 \mathrm{~s}\left(3 \mathrm{H}, \mathrm{H}^{2^{\prime}}, \mathrm{Py}\right), 9.10 \mathrm{~d}\left(3 \mathrm{H}, \mathrm{H}^{6^{\prime}}, \mathrm{Py}, J=5.5\right)$, $9.02 \mathrm{~d}\left(2 \mathrm{H}, \mathrm{H}^{8,12}, J=4.5\right), 8.89 \mathrm{~s}\left(4 \mathrm{H}, \mathrm{H}^{3,7,13,17}\right), 8.57 \mathrm{~d}$ $\left(2 \mathrm{H}, \mathrm{H}^{2,18}, J=4.5\right), 8.44 \mathrm{~d}\left(3 \mathrm{H}, \mathrm{H}^{4^{\prime}}, \mathrm{Py}, J=5.5\right), 8.27 \mathrm{~d}$ $\left(2 \mathrm{H}, \mathrm{H}^{2 \prime}, 6^{\prime \prime}, \mathrm{Ph}, J=6.0\right), 7.82-7.79 \mathrm{~m}\left(5 \mathrm{H}, \mathrm{H}^{5^{\prime}}, \mathrm{Py}, \mathrm{H}^{3 \prime}, 5^{\prime \prime}\right.$, $\mathrm{Ph}), 8.02 \mathrm{~d}(2 \mathrm{H}$, benzothiazole, $J=8.2), 7.46-7.54 \mathrm{~m}$ $(2 \mathrm{H}$, benzothiazole), $-2.78 \mathrm{~s}(2 \mathrm{H}, \mathrm{NH})$. Mass spectrum (MALDI-TOF), $m / z: 750.89[M]^{+} . \mathrm{C}_{48} \mathrm{H}_{30} \mathrm{~N}_{8} \mathrm{~S} . M 750.87$.

5-[4-(1,3-Benzothiazol-2-yl)phenyl]-10,15,20tris(1-methylpyridinium-3-yl)porphyrin triiodide (1a). A mixture of $0.22 \mathrm{~g}(0.29 \mathrm{mmol})$ of 5-[4-(1,3-benzothiazol2-yl)phenyl]-10,15,20-tris(pyridin-3-yl)porphyrin and $0.5 \mathrm{~mL}(0.46 \mathrm{mmol})$ of methyl iodide was refluxed in $30 \mathrm{~mL}$ of dimethylformamide during $1 \mathrm{~h}$. The solution was cooled down and diluted with benzene $(1: 1)$. The precipitate was filtered off, washed with benzene and acetone, and dried. Yield $0.21 \mathrm{~g}(98 \%)$. Electronic absorption spectrum (water), $\lambda_{\max }, \mathrm{nm}(\log \varepsilon): 418(6.09)$, 516 (4.69), 549 (4.63), 585 (4.65), 634 (4.65). ${ }^{1} \mathrm{H}$ NMR spectrum (DMSO- $\left.d_{6}\right), \delta$, ppm: $9.52 \mathrm{~s}\left(3 \mathrm{H}, \mathrm{H}^{2^{\prime}}, \mathrm{Py}\right), 9.11 \mathrm{~d}$ $\left(3 \mathrm{H}, \mathrm{H}^{6^{\prime}}, \mathrm{Py}, J=5.3\right), 9.02 \mathrm{~d}\left(2 \mathrm{H}, \mathrm{H}^{8,12}, J=4.4\right), 8.89 \mathrm{~s}$ $\left(4 \mathrm{H}, \mathrm{H}^{3,7,13,17}\right), 8.57 \mathrm{~d}\left(2 \mathrm{H}, \mathrm{H}^{2,18}, J=4.4\right), 8.44 \mathrm{~d}\left(3 \mathrm{H}, \mathrm{H}^{4^{\prime}}\right.$, 
Py, $J=5.2), 8.27 \mathrm{~d}\left(2 \mathrm{H}, \mathrm{H}^{2 \prime \prime}, 6^{\prime \prime}, \mathrm{Ph}, J=5.9\right), 7.82-7.79 \mathrm{~m}$ $\left(5 \mathrm{H}, \mathrm{H}^{5^{\prime}}, \mathrm{Py}, \mathrm{H}^{3 \prime}, 5^{\prime \prime}, \mathrm{Ph}\right), 7.94-8.11 \mathrm{~m}(2 \mathrm{H}$, benzothiazole), 7.46-7.54 m $(2 \mathrm{H}$, benzothiazole $), 4.72 \mathrm{~s}\left(9 \mathrm{H}, \mathrm{CH}_{3} \mathrm{~N}\right)$, -2.78 br. s $(2 \mathrm{H}, \mathrm{NH})$. Mass spectrum (MALDI-TOF), $m / z: 1176.73[M]^{+} . \mathrm{C}_{51} \mathrm{H}_{39} \mathrm{I}_{3} \mathrm{~N}_{8} \mathrm{~S} . M 1176.69$.

5-[4-(1,3-Benzoxazol-2-yl)phenyl]-10,15,20tris(pyridin-3-yl)porphyrin was prepared similarly to 5-[4-(1,3-benzothiazol-2-yl)phenyl]-10,15,20tris(pyridin-3-yl)porphyrin using $0.159 \mathrm{~g}$ (2 eq., $1.342 \mathrm{mmol}$ ) of benzoxazole instead of benzothiazole. Yield $0.395 \mathrm{~g}$ (79\%), green-violet crystalline powder. $R_{\mathrm{f}} 0.73$ (Silufol, dichloromethane-methanol, $10: 1$ ). Electronic absorption spectrum (dichloromethane), $\lambda_{\text {max }}, \mathrm{nm}(\log \varepsilon): 420$ (5.97), 516 (4.67), 551 (4.57), 590 (4.62), 646 (4.62). ${ }^{1} \mathrm{H}$ NMR spectrum $\left(\mathrm{CDCl}_{3}\right), \delta$, ppm $(J, \mathrm{~Hz}): 9.50 \mathrm{~s}\left(3 \mathrm{H}, \mathrm{H}^{2}, \mathrm{Py}\right), 9.10 \mathrm{~d}\left(3 \mathrm{H}, \mathrm{H}^{6^{\prime}}, \mathrm{Py}, J=5.5\right)$, $9.02 \mathrm{~d}\left(2 \mathrm{H}, \mathrm{H}^{8,12}, J=4.5\right), 8.89 \mathrm{~s}\left(4 \mathrm{H}, \mathrm{H}^{3,7,13,17}\right), 8.57 \mathrm{~d}$ $\left(2 \mathrm{H}, \mathrm{H}^{2,18}, J=4.5\right), 8.44 \mathrm{~d}\left(3 \mathrm{H}, \mathrm{H}^{4^{\prime}}, \mathrm{Py}, J=5.5\right), 8.26 \mathrm{~d}$ $\left(2 \mathrm{H}, \mathrm{H}^{2 \prime \prime}, 6^{\prime \prime}, \mathrm{Ph}, J=6.0\right), 7.82-7.80 \mathrm{~m}\left(5 \mathrm{H}, \mathrm{H}^{5^{\prime}}, \mathrm{Py}\right.$, $\left.\mathrm{H}^{3 \prime,} 5^{\prime \prime}, \mathrm{Ph}\right), 7.58-8.02 \mathrm{~m}$ (2H, benzoxazole), 7.34-7.43 $\mathrm{m}(2 \mathrm{H}$, benzoxazole $),-2.79 \mathrm{~s}(2 \mathrm{H}, \mathrm{NH})$. Mass spectrum (MALDI-TOF), $m / z: 734,83[M]^{+} . \mathrm{C}_{48} \mathrm{H}_{30} \mathrm{~N}_{8}$. M 734 80 .

5-[4-(1,3-Benzoxazol-2-yl)phenyl]-10,15,20tris(1-methylpyridinium-3-yl)porphyrin triiodide (1b) was obtained similarly to compound $\mathbf{1 a}$ from 5-[4-(1,3-benzoxazol-2-yl)phenyl]-10,15,20-tris(pyridin3 -yl)porphyrin. Yield $0.23 \mathrm{~g}(98 \%)$, brown crystalline powder. Electronic absorption spectrum (water), $\lambda_{\max }$, $\mathrm{nm}(\log \varepsilon): 418$ (6.05), 516 (4.67), 550 (4.64), 585 (4.64), 634 (4.66). ${ }^{1} \mathrm{H}$ NMR spectrum (DMSO- $\left.d_{6}\right), \delta, \operatorname{ppm}(J$, $\mathrm{Hz}): 9.51 \mathrm{~s}\left(3 \mathrm{H}, \mathrm{H}^{2}, \mathrm{Py}\right), 9.10 \mathrm{~d}\left(3 \mathrm{H}, \mathrm{H}^{6^{\prime}}, \mathrm{Py}, J=5.4\right)$, $9.02 \mathrm{~d}\left(2 \mathrm{H}, \mathrm{H}^{8,12}, J=4.4\right), 8.90 \mathrm{~s}\left(4 \mathrm{H}, \mathrm{H}^{3,7,13,17}\right), 8.57 \mathrm{~d}$ $\left(2 \mathrm{H}, \mathrm{H}^{2,18}, J=4.4\right), 8.44 \mathrm{~d}\left(3 \mathrm{H}, \mathrm{H}^{4^{\prime}}, \mathrm{Py}, J=5.5\right), 8.26 \mathrm{~d}$ $\left(2 \mathrm{H}, \mathrm{H}^{2 \prime}, 6^{\prime \prime}, \mathrm{Ph}, J=5.9\right), 7.82-7.80 \mathrm{~m}\left(5 \mathrm{H}, \mathrm{H}^{5^{\prime}}, \mathrm{Py}\right.$, $\left.\mathrm{H}^{3^{\prime \prime}, 5^{\prime \prime}}, \mathrm{Ph}\right), 7.58-8.02 \mathrm{~m}(2 \mathrm{H}$, benzoxazole $), 7.34-7.43 \mathrm{~m}$ $(2 \mathrm{H}$, benzoxazole $), 4.71 \mathrm{~s}\left(9 \mathrm{H}, \mathrm{CH}_{3} \mathrm{~N}\right),-2.79$ c $(2 \mathrm{H}$, $\mathrm{NH}$ ). Mass spectrum (MALDI-TOF), $m / z: 1160.67[M]^{+}$. $\mathrm{C}_{51} \mathrm{H}_{39} \mathrm{I}_{3} \mathrm{~N}_{8} \mathrm{O} . M 1160.62$.

5-[4-(1-Methyl-1,3-benzimidazol-2-yl)phenyl]10,15,20-tris(pyridin-3-yl)porphyrin was obtained similarly to 5-[4-(1,3-benzothiazol-2-yl)-phenyl]10,15,20-tris(1-methylpyridin-3-yl)porphyrin using $0.178 \mathrm{~g}$ ( 2 eq., $1.342 \mathrm{mmol}$ ) of 1-methylimidazole instead of benzothiazole. Yield $0.228 \mathrm{~g}(45 \%)$, green-violet crystalline powder. $R_{\mathrm{f}} 0.70$ (Silufol, dichloromethanemethanol, $10: 1)$. Electronic absorption spectrum (dichloromethane), $\lambda_{\max }, \mathrm{nm}(\log \varepsilon): 420$ (5.97), 516 (4.67), 550 (4.62), 590 (4.59), 646 (4.62). ${ }^{1} \mathrm{H}$ NMR spectrum $\left(\mathrm{CDCl}_{3}\right), \delta, \operatorname{ppm}(J, \mathrm{~Hz}): 9.50 \mathrm{~s}\left(3 \mathrm{H}, \mathrm{H}^{2}, \mathrm{Py}\right)$, $9.10 \mathrm{~d}\left(3 \mathrm{H}, \mathrm{H}^{6^{\prime}}, \mathrm{Py}, J=5.5\right), 9.02 \mathrm{~d}\left(2 \mathrm{H}, \mathrm{H}^{8,12}, J=\right.$ $4.5), 8.89 \mathrm{~s}\left(4 \mathrm{H}, \mathrm{H}^{3,7,13,17}\right), 8.57 \mathrm{~d}\left(2 \mathrm{H}, \mathrm{H}^{2,18}, J=4.5\right)$, $8.44 \mathrm{~d}\left(3 \mathrm{H}, \mathrm{H}^{4^{\prime}}, \mathrm{Py}, J=5.5\right), 8.26 \mathrm{~d}\left(2 \mathrm{H}, \mathrm{H}^{2^{\prime \prime}} 6^{\prime \prime}, \mathrm{Ph}, J=\right.$ 6.0), 7.82-7.80 m (5H, H $\left.\mathrm{H}^{5^{\prime}}, \mathrm{Py}, \mathrm{H}^{3^{\prime \prime}, 5^{\prime \prime}}, \mathrm{Ph}\right), 7.59 \mathrm{~d}(2 \mathrm{H}$, imidazole, $J=8.4), 7.42-7.47 \mathrm{~m}(2 \mathrm{H}$, imidazole $), 3.88 \mathrm{~s}$ $(3 \mathrm{H}, \mathrm{NMe}),-2.78 \mathrm{c}(2 \mathrm{H}, \mathrm{NH})$. Mass spectrum (MALDITOF), $m / z$ : $747.36[M]^{+} . \mathrm{C}_{49} \mathrm{H}_{33} \mathrm{~N}_{9}$. M 747.29.

5-[4-(1-Methyl-1,3-benzimidazol-2-yl)phenyl]10,15,20-tris(1-methylpyridinium-3-yl)porphyrin triiodide (1c) was obtained similarly to compound $\mathbf{1 a}$ from 5-[4-(1-methyl-1,3-benzimidazol-2-yl)phenyl10,15,20-tris(pyridin-3-yl)porphyrin. Yield $0.19 \mathrm{~g}$ (99\%), brown crystalline powder. Electronic absorption spectrum (water), $\lambda_{\max }, \mathrm{nm}(\log \varepsilon): 418$ (6.07), $516(4.69)$, 550 (4.65), 585 (4.63), 634 (4.64). ${ }^{1} \mathrm{H}$ NMR spectrum $\left(\mathrm{DMSO}-d_{6}\right), \delta, \operatorname{ppm}(J, \mathrm{~Hz}): 9.50 \mathrm{~s}\left(3 \mathrm{H}, \mathrm{H}^{2}, \mathrm{Py}\right), 9.10 \mathrm{~d}$ $\left(3 \mathrm{H}, \mathrm{H}^{6^{\prime}}, \mathrm{Py}\right), 9.02 \mathrm{~d}\left(2 \mathrm{H}, \mathrm{H}^{8,12}, J=4.4\right), 8.89 \mathrm{~s}(4 \mathrm{H}$, $\left.\mathrm{H}^{3,7,13,17}\right), 8.57 \mathrm{~d}\left(2 \mathrm{H}, \mathrm{H}^{2,18}, J=4.4\right), 8.44 \mathrm{~d}\left(3 \mathrm{H}, \mathrm{H}^{4^{\prime}}, \mathrm{Py}\right.$, $J=5.3), 8.26 \mathrm{~d}\left(2 \mathrm{H}, \mathrm{H}^{2 \prime}, 6^{\prime \prime}, \mathrm{Ph}, J=6.0\right), 7.83-7.80 \mathrm{~m}(5 \mathrm{H}$, $\left.\mathrm{H}^{5^{\prime}}, \mathrm{Py}, \mathrm{H}^{3^{\prime \prime}, 5^{\prime \prime}}, \mathrm{Ph}\right), 7.59 \mathrm{~d}(2 \mathrm{H}$, imidazole), 7.42-7.47 m $\left(2 \mathrm{H}\right.$, imidazole), $4.72 \mathrm{~s}\left(9 \mathrm{H}, \mathrm{CH}_{3} \mathrm{~N}\right), 3.89 \mathrm{~s}(3 \mathrm{H}, \mathrm{NMe})$, $-2.78 \mathrm{~s}(2 \mathrm{H}, \mathrm{NH})$. Mass spectrum (MALDI-TOF), $\mathrm{m} / \mathrm{z}$ : $1173.74[M]^{+} . \mathrm{C}_{52} \mathrm{H}_{42} \mathrm{I}_{3} \mathrm{~N}_{9} . M 1173.66$.

\section{AUTHOR INFORMATION}

S.A. Syrbu, ORCID: http://orcid.org/0000-0003-1482-2809

A.N. Kiselev, ORCID: http://orcid.org/0000-0002-66646221

M.A. Lebedev, ORCID: http://orcid.org/0000-0002-93183816

Yu.A. Gubarev, ORCID: http://orcid.org/0000-0003-28702189

E.S. Yurina, ORCID: http://orcid.org/0000-0002-2403-7049

N.S. Lebedeva, ORCID: http://orcid.org/0000-0001-72603239

\section{FUNDING}

This study was financially supported by the Russian Foundation for Basic Research (project no. 20-04-60067) and performed using the equipment of the Center for Collective Usage, Ivanovo State University of Chemistry and Technology.

\section{CONFLICT OF INTEREST}

No conflict of interest was declared by the authors. 


\section{REFERENCES}

1. Wu, Y., Xu, X., Chen, Z., Duan, J., Hashimoto, K., Yang, L., Liu, C., and Yang, C., Brain Behav. Immun., 2020, vol. 87, p. 18.

https://doi.org/10.1016/j.bbi.2020.03.031

2. Jahanshahlu, L. and Rezaei, N., Arch. Med. Res., 2020, vol. 51, no. 7, p. 721 .

https://doi.org/10.1016/j.arcmed.2020.05.016

3. Gandhi, S., Srivastava, A.K., Ray, U., and Tripathi, P.P., ACS Chem. Neurosci., 2020, vol. 11, no. 10, p. 1379. https://doi.org/10.1021/acschemneuro.0c00217

4. Hamming, I., Timens, W., Bulthuis, M.L., Lely, A.T., Navis, G.J., and Goor, H., J. Pathol., 2004, vol. 203, no. 2 , p. 631 .

https://doi.org/10.1002/path.1570

5. Drake, J.W., PNAS, 1993, vol. 90, no. 9, p. 4171.

https://doi.org/10.1073/pnas.90.9.4171

6. Villa, T.G., Abril, A.G., Sánchez, S., Miguel, T., and Sánchez-Pérez, A., Arch. Microbiol., 2020, p. 1.

https://doi.org/10.1007/s00203-020-02040-5

7. Thébaud, G., Chadœuf, J., Morelli, M.J., McCauley, J.W., and Haydon, D.T., Proc. Royal. Soc. (B), 2010, vol. 277, no. 1682 , p. 809.

https://doi.org/10.1098/rspb.2009.1247

8. Cheng, L., Han, X., Zhu, Z., Qi, C., Wang, P., and Zhang, X., Brief. Bioinformatics., 2021, vol. 22, no. 2, p. 1442.

https://doi.org/10.1093/bib/bbab042

9. Wu, C., Liu, Y., Yang, Y., Zhang, P., Zhong, W., Wang, Y., Xu, Y., Li, M., Li, X., Zheng, M., Chen, L., and Li, H., Acta Pharm. Sin. B, 2020, vol. 10, no. 5, p. 766. https://doi.org/10.1016/j.apsb.2020.02.008

10. Basu, A., Sarkar, A., and Maulik, U., Sci. Rep., 2020, vol. 10, no. 1, p. 1. https://doi.org/10.1038/s41598-020-74715-4.

11. Charoute, H., Saile, R., and Barakat, A., ChemRxiv. Preprint., 2020.

https://doi.org/10.26434/chemrxiv.12115638.v1

12. Narkhede, R.R., Cheke, R.S., Ambhore, J.P., and Shinde, S.D., Eurasian J. Med. Oncol., 2020, vol. 4 , no. 3 , p. 185 .

https://doi.org/10.14744/ejmo.2020.31503

13. Wan Y. Shang, J., Graham, R., Baric, R.S., and Li, F., J. Virol., 2020, vol. 94, no. 7, p. 1. https://doi.org/10.1128/JVI.00127-20

14. Habtemariam, S., Nabavi, S.F., Banach, M., BerindanNeagoe, I., Sarkar, K., Sil, P.C., and Nabavi, S.M., Arch. Med. Res., 2020, vol. 51, no. 7, p. 733. https://doi.org/10.1016/j.arcmed.2020.05.024

15. Yan, L., Zhang, Y., Ge, J., Zheng, L., Gao, Y., Wang, T., Huang, Y., Li, M., Wang, Q., Rao, Z., and Lou, Z., Nat. Commun., 2020, vol. 11, no. 1, p. 1. https://doi.org/10.1038/s41467-020-19770-1

16. Borgio, J.F., Alsuwat, H.S., Al Otaibi, W.M., Ibrahim, A.M., Almandil, N.B., Al Asoom, L.I., Salahuddin, M., Kamaraj, B., and AbdulAzeez, S.,
Arch. Med. Sci., 2020, vol. 16, no. 3, p. 508.

https://doi.org/10.5114/aoms.2020.94567

17. Ugurel, O.M., Mutlu, O., Sariyer, E., Kocer, S., Ugurel, E., Inci, T.G., Ata, O., and Turgut-Balik, D., Int. J. Biol. Macromol., 2020, vol. 163, p. 1687. https://doi.org/10.1016/j.ijbiomac.2020.09.138

18. Khater, S. and Das, G., OSFPREPRINTS, 2020, p. 1. https://doi.org/10.31219/osf.io/8dseq

19. Balasubramaniam, M. and Reis, R.J.S., ChemRxiv., 2020. https://doi.org/10.26434/chemrxiv.12084822

20. Gurung, A.B., Gene Rep., 2020, vol. 21, p. 100860. https://doi.org/10.1016/j.genrep.2020.100860

21. White, M.A., Lin, W., and Cheng, X., J. Phys. Chem. Lett., 2020, vol. 11, no. 21, p. 9144. https://doi.org/10.1021/acs.jpclett.0c02421

22. Vzorov, A.N., Dixon, D.W., Trommel, J.S., Marzilli, L.G., and Compans, R.W., Antimicrob. Agents Chemother., 2002, vol. 46, no. 12, p. 3917. https://doi.org/10.1128/AAC.46.12.3917-3925.2002

23. Guo, H., Pan, X., Mao, R., Zhang, X., Wang, L., Lu, X., Chang, J., Guo, J.-T., Passic, S., Krebs, F.C. Wigdahl, B., Warren, T.K., Retterer, C.J., Bavari, S., Xu, X., Cuconati, A., and Block, T.M., Antimicrob. Agents Chemother., 2011, vol. 55, p. 478. https://doi.org/10.1128/AAC.00989-10

24. Abrahamse, H. and Hamblin, M.R., Biochem. J., 2016, vol. 473 , p. 347. https://doi.org/10.1042/BJ20150942

25. Hamblin, M.R. and Abrahamse, H., Antibiotics, 2020, vol. 9, p. 53. https://doi.org/10.3390/antibiotics9020053

26. Majiya, H., Adeyemi, O.O., Stonehouse, N.J., and Millner, P., J. Photochem. Photobiol. (B), 2018, vol. 178, p. 404. https://doi.org/10.1016/j.jphotobiol.2017.11.032

27. Mirza, M.U. and Froeyen, M., J. Pharm. Anal., 2020, vol. 10 , no. 4 , p. 320. https://doi.org/10.1016/j.jpha.2020.04.008

28. Davies, M.J., Truscott, R.J.W., J. Photochem. Photobiol. (B), 2001, vol. 63, no. 1-3, p. 114. https://doi.org/10.1016/S1011-1344(01)00208-1

29. Rodgers, M.A.J. and Snowden, P.T., J. Am. Chem. Soc., 1982, vol. 104, no. 20, p. 5541. https://doi.org/10.1021/ja00384a070

30. Moan, J., J. Photochem. Photobiol. (B), 1990, vol. 6, no. 3, p. 343. https://doi.org/10.1016/1011-1344(90)85104-5

31. Hatz, S., Poulsen, L., and Ogilby, P.R., Photochem. Photobiol., 2008, vol. 84, no. 5, p. 1284. https://doi.org/10.1111/j.1751-1097.2008.00359.x

32. Neese, F., Wiley Interdiscip. Rev. Comput. Mol. Sci., 2018, vol. 8, no. 1, p. e1327. https://doi.org/10.1002/wcms.1327

33. Trott, O. and Olson, A.J., J. Comput. Chem., 2010, vol. 31 , no. 2 , p. 455 .

https://doi.org/10.1002/jcc. 21334 